Written in the Flesh is a history of sexual desire - a provocative chronicle of the changing nature of what people yearn to do sexually.

The desire for sexual pleasure and total body sex - that is, the expansion of sexuality from a limited focus on the face and genitals to include the entire body - is certainly not a new phenomenon: the ancient Greeks, Romans, and Chinese, among others, were quite familiar with an eroticism that went beyond the strictly heterosexual and procreational. In the long centuries of Christian Europe, when the miserable conditions of life and religious repression conspired to minimize the expression of sexual longing, desire was driven underground. Yet in the late nineteenth century, increasing privacy, prosperity, and good health again permitted the underlying biological urge for total body sex to express itself, and encouraged a shift of erotic pleasure toward new and unexplored body zones: the mouth, nipples, anus, and further.

This new work by renowned medical historian Edward Shorter demonstrates that desire is hard-wired into the brain, expressing itself in remarkably similar ways in men and women, adolescent and adult, and in gays, lesbians, and straights alike. Drawing from a wide array of sources, including memoirs, novels, collections of letters, diaries, and indeed a large pornographic corpus, Shorter explores the widening of Western society's sexual repertoire.

Written in the Flesh is a history of what people like to do in bed and how that has changed. The change is relentless: human sexuality continually seeks new means of liberation in its expression of pleasure.

EDWARD SHORTER holds the Jason A. Hannah Chair in the History of Medicine at the University of Toronto. 
This page intentionally left blank 


\title{
Written in the Flesh
}

A History of Desire

\author{
EDWARD SHORTER
}

UNIVERSITY OF TORONTO PRESS

Toronto Buffalo London 
(C) Edward L. Shorter 2005

University of Toronto Press

Toronto Buffalo London

Printed in Canada

Reprinted in paperback 2006

ISBN 0-8020-3843-3 (cloth)

ISBN 0-8020-9452-X (paper)

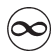

Printed on acid-free paper

\section{Library and Archives Canada Cataloguing in Publication}

Shorter, Edward

Written in the flesh : a history of desire / Edward Shorter.

Includes bibliographical references and index. ISBN 0-8020-3843-3 (bound). - ISBN 0-8020-9452-X (pbk.)

1. Sex - Western countries - History. 2. Desire - History.

3. Sensuality - History. I. Title.

HQ21.S482 2005 306.7'09 C2005-900164-X

Every effort has been made to obtain permission to reproduce the illustrations in this book. Any omissions brought to our attention will be rectified in future printings of this book.

University of Toronto Press acknowledges the financial assistance to its publishing program of the Canada Council for the Arts and the Ontario Arts Council.

University of Toronto Press acknowledges the financial support for its publishing activities of the Government of Canada through the

Book Publishing Industry Development Program (BPIDP). 
For my dearest Anne Marie 
This page intentionally left blank 